\title{
The discovery of Antillean algal taxa described by Duchassaing in 1850
}

\author{
Michael J. Wynne \\ University of Michigan, Department of Ecology and Evolutionary Biology, Ann Arbor, Michigan
}

\begin{abstract}
This note is to call attention to a number of marine algal taxa from the Antilles that were described by Placide Duchassaing in his 1850 work Animaux radiaires des Antilles. The mid- $19^{\text {th }}$ century was a period when the distinction between marine invertebrates and some calcified benthic marine algae was still not always clear. The names of these algal taxa were validated, although no figures or details on their specific provenance were provided, other than they were from Duchassaing's collections from the Antilles. Duchassaing assigned his new algal species to the following genera: Galaxaura, Amphiroa, Jania, Melobesia and Nullipora.
\end{abstract}

Keywords:

Caribbean, Duchassaing, Guadeloupe, marine algae

Submitted: June 3, 2014

Revised: July 21, 2014 Accepted: October 6, 2014

\section{Introduction}

[Édouard] Placide Duchassaing [de Fontbressin] was born in Moule on Guadeloupe on 1 Dec. 1818, born into a family of French-Creole planters (Sagot 1873; Wiedenmayer 1977). He obtained his medical degree in Paris and returned to practice medicine on Guadeloupe (Stafleu \& Mennega 2010). Because of social unrest on Guadeloupe, he left and traveled to various other islands, including Nevis, St. Eustatius, St. Martin, and apparently also St. Barthélmy, St. Croix, and Cuba, while also treating outbreaks of cholera (Wiedenmayer 1977). Duchassaing began his serious collecting of natural objects (plants and animals) in the period 1844-1848, with evidence of his having collected plants and algae on the island of Guadeloupe. In 1848 he lived in Santa Marta near Panama, where he stayed for a period until again being driven out by unrest. He next moved to Copenhagen and obtained a Danish degree in medicine about 1850. He returned to Guadeloupe in 1851, and later moved to St. Thomas. He returned to France in 1867 with his wife and children (Sagot 1873). He died on 16 Sept. 1873, in Périgord (Urban 1902; Wiedenmayer 1977; Stafleu \& Mennega 2010).

Correspondence: Dr. Wynne, 3600 Varsity Drive, Ann Arbor, Michigan 48108, United States

E-Mail: mwynne@umich.edu
Duchassaing's major interests and contributions were zoological rather than botanical. He published early important works on sponges, corals, and other invertebrates of the western Atlantic Ocean. He started to collect sponges in 1848 and published his first paper on them in 1850. In 1855, he met a visiting Italian lawyer, Giovanni Michellotti, who spent several months in the West Indies. The two became friends and collaborators in their mutual interest in sponges and in 1864 published their Spongiaires de la mer Caraibe. The following works can be found online at the Biodiversity Heritage Library site: Duchassaing 1870; Duchassaing \& Michelotti 1860, 1864.

\section{Results}

An examination of Duchassaing's (1850) Animaux radiaires des Antilles revealed that he included benthic marine algae in this treatment and even described a dozen new species. These newly validated algal names have apparently escaped the attention of later workers. This paper as well as some other Duchassaing publications are posted online at the Gallica Bibliothéque Numérique site: http://gallica.bnf.fr/. Under his "Corallinaires", Duchassaing (1850) included species in the following genera: Nesea [Nesaea] Lamx. [= Penicillus Lam.], Cephalothrix Duchass., Udotea Lamx., Halymeda 
[Halimeda] Lamx., Galaxaura Lamx., Amphiroa Lamx. Jania Lamx., Neomeris Lamx., Nullipora Lam. and Melobesia Lamx. Thus, he listed numerous species that had already been described by Ellis \& Solander or treated by Lamarck and Lamouroux. The previously described species will not be listed here. Only the newly validated names of algae are listed below. Their descriptions can be found in Duchassaing (1850) online

Galaxaura cuneiformis Duchass. p. 30.

Amphiroa longa Duchass. p. 30.

Amphiroa laurentii Duchass. p. 30.

Amphiroa abbreviata Duchass. p. 31.

Amphiroa desmoulini Duchass. p. 31.

Jania lesuerii Duchass. p. 31.

Jania caespitosa Duchass. p. 31.

Jania continua Duchass. p. 31

Nullipora lichenoides Duchass. nom. illeg. p. 32.

The Duchassaing name is a later homonym of Nullipora lichenoides (J. Ellis \& Solander) Templeton (1836), which was based on Millepora lichenoides J. Ellis \& Solander (1786).

Nullipora erecta Duchass. p. 32.

Melobesia mamillaris Duchass. nom. illeg. p. 32.

The Duchassaing name is a later homonym. This same binomial had been validated the previous year by Harvey (1849), who cited collections from syntype localities of Bahia, Brazil; Tierra del Fuego; Ilhas do Cabo Verde; and Algoa Bay, Cape Province, South Africa. The Harvey species is currently known as Neogoniolithon mamillare (Harv.) Setch. \& L. R. Mason.

Melobesia exasperata Duchass. p. 33.

\section{Discussion and conclusions}

Duchassaing's newly validated algal taxa have escaped attention over the years from the broad treatises of algal names compiled by Agardh (1851-1863, 1876, 1880, 1898, 1901) and De Toni (1897, 1900, 1903, 1905, $1924)$ as well as by Murray (1888-1889) and the contemporary online databases of "Index Nominum Algarum" (Silva 2014) and AlgaeBase (Guiry \& Guiry 2014). The names of the crustose corallines are not included in Woelkerling \& Lamy (1998). No figures were provided by Duchassaing, and the descriptions were brief, mostly only 2 or 3 lines.

The question is: Do type specimens of these algal species described by Duchassaing still exist, and if so, where are they? Duchassaing's modus operandi was to send his specimens to European authorities, and these authorities typically deposited these specimens in their home institutions. So because the Italian friend and coauthor Michelloti received many of the animals (primarily sponges and corals), he deposited them in the Museum in Turin [Torino], Italy (Wiedenmayer 1977; Soest et al.
1983; Alvarez et al. 1998; Volpi \& Benvenuti 2003). Terrestrial plant specimens collected by Duchassaing in Guadeloupe were sent to the botanist Walpers in Berlin, and after Walpers' death the collections were sent on to Grisebach in Göttingen. Both Walpers and Grisebach had publications on Duchassaing's collections of terrestrial plants (Duchassaing \& Walpers 1851; Griesbach 1857). According to Urban (1902), the Berlin Museum at that time contained the Guadeloupe collections as well as a large collection of Duchassaing's algae, fungi, lichens, and mosses. The herbarium at Berlin, Dahlem, suffered tremendous damage from aerial bombing in 1943, during World War II (Hiepko 1987). According to Sayer (1975), besides the part of Duchassaing's collections that went to Walpers in Berlin, another part went to Paris, in fact, more than 2,000 specimens from him in the period 1844-1852. These included algae, lichens, and bryophytes. Sayre indicated that the labels of these in $\mathrm{PC}$ were in elaborate, multigraphed handwriting, with data on the collections, but they were mostly unnamed.

According to Stafleu \& Mennega (2000), the first set of Duchassaing's plant collections was left in GOET and the second set in $\mathrm{B}$, but additional specimens are located in another twelve herbaria $(\mathrm{CN}, \mathrm{DBN}, \mathrm{F}, \mathrm{HH}, \mathrm{K}$, LL, LY, LZ, M, MO, NY, and P) (Thiers, 2014). According to Miquel (2012), Duchassaing's algal collections are now conserved in the herbaria of Paris (PC), New York (NY), and Goettingen (GOET).

An online search of the PC Herbarium site did not reveal any Duchassaing algal collections. This was accompanied by a separate search made by Dr. Bruno de Reviers, who was unable to locate any Duchassaing algal specimens in PC. An online search of them at the C. V. Starr Virtual Herbarium at NY showed the presence of three of Duchassaing collections of algae: Ectocarpus clavifer and Mesotrema pavonia, both described by Agardh (1854), and Meristotheca duchassaingii, later described by Agardh (1872). There were no types of the species described by Duchassaing (1850) in either of these databases.

At my request, Dr. Appelhans, Curator of the GOET Herbarium, made a search for Duchassaing-collected algal specimens, primarily looking for any Types of the species that Duchassaing described in 1850. Dr. Appelhans reported back that he found in GOET Duchassaing collections of Melobesia spp. and Galaxaura spp. from Guadeloupe but no specimens that are Types of the new species validated by Duchassaing. Dr. Regine Jahn at the Herbarium of the Botanisches Museum BerlinDahlem kindly searched their holdings and did not find any Duchassaing algal collections. Likewise, Dr. Dagmar Triebel conducted a search in the holdings of the Munich Herbarium but without success.

Duchassaing's name has been used as a specific honorific by a number of workers, who cited him as the 
collector. On the basis of a Duchassaing collection from Guadeloupe, Agardh (1854) described Bryopsis duchassaingii, which is now known as Trichosolen duchassaingii (J. Agardh) W. R. Taylor (Taylor 1962). Grunow (1868) described Ectocarpus duchassaingianus, which is now called Feldmannia duchassaingiana (Grunow) Aisha \& Shameel (Aisha \& Shameel 2011). Agardh's (1872) Meristotheca duchassaingii from Guadeloupe is currently known as Halymenia duchassaingii (J. Agardh) Kylin (Kylin 1932).

The purpose of this contribution is to call attention to these algal names validated by Duchassaing (1850) for his own collections made in Guadeloupe, hoping that other workers may come across the Types, which now appear to be missing.

The author is grateful to the following persons who have given me assistance on this project: Dr. Bruno de Reviers (Muséum National d'Histoire Naturelle, Paris), Dr. Regine Jahn, (Herbarium Berlin, Dahlem, Germany), Dr. Marc Applehans (University of Goettingen, Germany), Dr. Dagmar Triebel (Munich Herbarium, Germany), Dr. Rob van Soest (Naturalis Biodiversity Center, Amsterdam), and Dr. Robert Thacker (University of Alabama, Birmingham).

\section{References}

Agardh, J. G. 1851-1863: Species genera et ordines algarum. Vol. 2. - Lundae [Lund].

Agardh, J. G. 1854: Nya algformer. - Öfvers. Kongel. [Svenska] Vetensk.-Akad. Förhandl. 11(4): 107-111.

Agardh, J. G. 1872: Bidrag till Florideernes systematik. - Lunds Univ. Års-Skrift, Afdel. Math. Naturvetsenskap 2, 8(6): 1-60.

Agardh, J. G. 1876: Species genera et ordines algarum. Vol. 3 (part 1). - Lundae [Lund].

Agardh, J. G. 1880: Species genera et ordines algarum. Vol. 3 (part 2). - Lundae [Lund]

Agardh, J. G. 1898: Species genera et ordines algarum. Vol. 3 (part 3). - Lundae [Lund].

Agardh, J. G. 1901: Species genera et ordines algarum. Vol. 3 (part 4). - Lundae [Lund].

Aisha, K. \& Shameel, M. 2011: Taxonomic study of the order Ectocarpales (Phaeophycota) from the coastal waters of Pakistan. - Internat'l J. Algae 13: 128-148.

Alvarez, B., van Soest, R. W. M. \& Ruetzler, K. 1998: A revision of Axinellidae (Porifera: Demospongiae) of the Atlantic region. - Smithson. Contr. Zool. 598: p. 47.

Biodiversity Heritage Library: http://www.biodiversitylibrary.org/

C. V. Starr Virtual Herbarium, The New York Botanical Garden. http://sciweb.nybg.org/science2/vii2.asp

De Toni, G. B. 1897: Sylloge algarum omnium hucusque cognitarum. Vol. 4. Sylloge Floridearum. Sec. 1. - Padova. i-xi, pp. 1-388.

De Toni, G. B. 1900: Sylloge algarum omnium hucusque cognitarum. Vol. 4. Sylloge Floridearum. Sec. 2. - Padova. i-iv, pp. 387-776.
De Toni, G. B. 1903: Sylloge algarum omnium hucusque cognitarum. Vol. 4. Sylloge Floridearum. Vol. 4. Sylloge Floridearum. Sec. 3. - Padova. i-v, pp. 775-1521.

De Toni, G. B. 1905: Sylloge algarum omnium hucusque cognitarum. Vol. 4. Sylloge Floridearum. Sec. 4. - Padova. pp. 1523-1973.

De Toni, G. B. 1924: Sylloge algarum omnium hucusque cognitarum. Vol. 6. Sylloge Floridearum Sect. 5. Additamenta. Padova. xi, p. 767.

Duchassaing, P. 1850: Animaux radiaires des Antilles. - Typographie Plon Frères, Paris. p. 33, pls. 2.

Duchassaing, P. 1870: Revue des zoophytes et des spongiaires des Antilles. - Victor Masson et Fils, Paris. p. 52, pls. 2.

Duchassaing, P. \& Michelotti, G. 1860: Mémoire sur les Coralliaires des Antilles. - Mém. Acad. Sci. Turin, sér. II, 19. p. 89, pls. 11.

Duchassaing, P. \& Walpers, G. 1851: Plantae novae et minus cognitae Isthmo Panamensi et in insulis Guadeloupe et Sti. Thomae collectae. - Linnaea 23: 737-756.

Duchassaing de Fonbressin \& Michelotti, G. 1864: Spongiaires de la mer Caraibe. - Mém. Soc. holland. sci. Harlem. Les héritiers, Loosjes. Ser. 2, 21(3): p. 124, pls. 25.

Ellis, J. \& Solander, D. 1768: The natural history of many curious and uncommon zoophytes, collected from various parts of the globe... - Benjamin White, London. xii + p. 208, pls. 63 .

Gallica Bibliothèque Numérique. Bibliothèque national de France. http://gallica.bnf.fr/

Griesbach, A. H. R. 1857: Systematische Untersuchugen über die Vegetation der Karaiben, insbesondere der Insel Guadeloupe. - Dietrich, Göttignen. p. 138.

Grunow, A. 1868 [1867]: Algae. In: E. Fenzl et al. (eds.), Reise der österreichischen Fregatte Novara um die Erde in den Jahre 1857, 1858, 1859. Botanischer Theil, Erster Band. Sporenpflanzen. - Wien [Vienna]. pp. [1]-104, pls. I, la, II-XI.

Guiry, M. D. \& Guiry, G. M. 2014: AlgaeBase. World-wide electronic publication, National University of Ireland, Galway. http://www.algaebase.org; searched on 15 May 2014.

Harvey, W. H. 1849: Nereis Australis, or Algae of the Southern Ocean. Part II: 65-124, pls 26-50. - Reeve, London.

Hiepko, P. 1987: The collections of the Botanical Museum Berlin-Dahlem (B) and their history. In: Scholz, H. (ed.), Botany in Berlin, on the occasion of the XIV International Botanical Congress. - Englera 7: 219-252.

Kylin, H. 1932: Die Florideenordnung Gigartinales. - Lunds Universitets Årsskrift, N. F., Andra Afdelningen 28: p. 88, pls. 28.

Miquel, S. 2012: Edmond Placide Duchassaing de Fontbressin, naturaliste et médicin périgordais (Guadeloupe, 1818 Périgeux, 1873). - Bull. Soc. hist. archéolog. Périgord 139: 217-226.

Murray, G. 1888-1889: Catalogue of the marine algae of the West Indian region. - J. Bot., Brit. \& For. 26: 193-196, $237-$ 243, 303-307, 331-338, 358-363. [1889] 27: 237-242, 257-262, 298-305.

PC Muséum National d'Histoire Naturelle, Paris: http://colhelper.mnhn.fr/basr/sonnerat.html

Sagot, P. 1873: Notice sur le Docteur Duchassaing. - Bull. Soc. Bot. Fr. 20: 275-280.

Sayre, G. 1975: Cryptogamae Exsiccatae - An annotated bibliography of exsiccatae of Algae, Lichenes, Hepaticae, and Musci. V. Unpublished exsiccatae. I. Collectors. Mem. New York. Bot. Gard. 19: 277-423.

Silva, P. C. 2014: Index Nominum Algarum. Bibliographica Phycologica Universalis. http://ucjeps.berkeley.edu/CPD/index.html 
Soest van, R. W. M., Stone, S. M., Boury-Esnault, N. \& Rützler, K. 1983: Catalogue of the Duchassaing \& Michelotti (1864) collection of West Indian sponges (Porifera). - Bull. Zool. Mus. Univ. Amsterdam 9(21): 189-205.

Stafleu, F. A. \& E. A. Mennega, 2000: Taxonomic literature. Suppl. VI. Do-E. - Regnum Vegetabile 137. Koeltz Scientific Books, Königstein, Germany. vi + p. 518 .

Taylor, W. R. 1962: Observations on Pseudobryopsis and Trichosolen (Chlorophyceae-Bryopsidaceae) in America. Brittonia 14: 58-65.

Templeton, R. 1836: A catalogue of the species of annulose animals and rayed ones found in Ireland. - Mag. Nat. Hist. 9: 233-240, 301-305, 417-422, 466-472.

Thiers, B. 2014 [continuously updated]: Index Herbariorum: A global directory of public herbaria and associated staff. New
York Botanical Garden's Virtual Herbarium. http://sweetgum.nybg.org/ih/

Urban, I. 1902: Symbolae Antillanae..., Vol. 3. p. 546 - Fratres Borntraeger, Lipsiae.

Volpi, C. \& Benvenuti, D. 2003: The Duchassaing \& Michelotti collection of Caribbean corals; status of the types and location of the specimens. - Atti Soc. Ital. sci. nat. Mus. Civico storia nat. Milano 144: 51-74.

Wiedenmayer, F. 1977: Shallow-water sponges of the western Bahamas. - Birkhäuser Verlag, Basel \& Stuttgart. p. 287, pls. 43.

Woelkerling, W. J. \& Lamy, D. 1998: Non-geniculate coralline red algae and the Paris Muséum: systematics and scientific history. [With contributions by Dumont, M. \& de Reviers, B.]. - Publications Scientifiques du Muséum/A.D.A.C. Paris. viii + p. 767 . 